Article

\title{
Vitalizing Rural Communities: China's Rural Entrepreneurial Activities from Perspective of Mixed Embeddedness
}

\author{
Huasheng Zhu ${ }^{1,2}, *$, Yawei Chen ${ }^{2}$ and Kebi Chen ${ }^{2}$ \\ 1 Beijing Key Laboratory of Environmental Remote Sensing and Digital City, Beijing Normal University, \\ Beijing 100875, China \\ 2 Faculty of Geographical Science, Beijing Normal University, Beijing 100875, China; \\ ywchen@mail.bnu.edu.cn (Y.C.); chenkebi@mail.bnu.edu.cn (K.C.) \\ * Correspondence: zhuhs@bnu.edu.cn; Tel.: +86-10-5880-0193
}

Received: 30 January 2019; Accepted: 14 March 2019; Published: 17 March 2019

check for updates

\begin{abstract}
Rural entrepreneurial activities play an important role in the development of rural economies and the vitality of rural areas, and they can also contribute to an increase in the employment opportunities of farmers and environmental sustainability during China's transitional period. As a local organization, the community connects individuals, collective agencies, local authorities, and the market in reforming rural economies in China. Based on the concepts of mixed embeddedness and on the database of the China Family Panel Studies (CFPS), this paper uses a binary logistic regression (BLR) model to analyze the impact of social, institutional, and economic environments of rural communities on entrepreneurship. The finding shows that informal, entrepreneurship-oriented institutions in rural communities have more significantly positive impact on farmer entrepreneurship than formal institutions, as well as economic and social environments. Furthermore, compared with kinship, neighborhood relationships and weak ties based on the population mobility in rural communities are more important for farmer entrepreneurship. Additionally, rural communities are the production places and markets, and their economic levels are positively related to entrepreneurship. Last but not least, compared with urban communities, rural communities play a much more prominent role in local entrepreneurship.
\end{abstract}

Keywords: rural communities; farmer entrepreneurship; entrepreneurial activities; mixed embeddedness; China Family Panel Studies (CFPS)

\section{Introduction}

Entrepreneurial activities are a process of value creation and play a positive role in regional sustainable development [1]. As entrepreneurial activities are often embedded within local contexts, scholars have proposed the "contextualization" of entrepreneurship research [2]. Current research on entrepreneurship is mostly based within the context of Western developed countries, and there is relatively little research from developing countries, especially China, which is an emerging economy with burgeoning entrepreneurship. Moreover, while there have been many studies on urban entrepreneurial activities [3,4], the attention given to rural entrepreneurship is still relatively insufficient. Actually, the nature of the countryside is different from that of the city [5]. The natural environment, landscape, and agriculture of the countryside are sources of entrepreneurial capital that cannot be ignored. Moreover, compared to urban entrepreneurs, rural entrepreneurs have more prominent dual embeddedness, and in rural entrepreneurship, the value of the local environment and external network is of great importance [6]. 
Rural entrepreneurial activities are especially important to sustain the development of the rural area in China, as evidenced by such successful regional development cases as the "Wenzhou Model", the "Southern Jiangsu Model", and the "Jinjiang Model" (see Appendix A). However, little attention has been paid to Chinese rural entrepreneurship in international journals; only a small number of research papers on Chinese urban entrepreneurial activities have made an effort to combine the Chinese background with Western theories [7]. Actually, the social, economic, and institutional context of rural entrepreneurial activities has changed greatly. Although Chinese rural areas have made great changes and substantial development especially in the past 40 years, they are also faced with the same problems as those that developed countries have experienced, including the large-scale migration of the rural population and the decline of rural communities. The Chinese central government (CCG) has paid much attention to the role of rural community construction in increasing farmers' well-being, promoting sustainable agricultural development, and strengthening rural harmony and stability. Also, after proposing its strategy of "mass entrepreneurship and innovation" in the urban and rural areas, the CCG has carried out its Rural Revitalization Strategy (2018-2022) [8], emphasizing that "a nation will prosper only when its village thrives; a nation will weaken when its village is left behind". Those policies received a positive response from local governments. Optimizing the environment for rural innovation and entrepreneurship, and attracting more investments from young people and even foreigners, are supposed to be helpful for rural revitalization and sustainable development [9]. It urges that more academic focus be paid to the rural areas, and the impact of interactions between small and micro entrepreneurs in rural areas and the community environment where they live still be enhanced [10]. Do the changing social, economic, and institutional factors in the rural areas of China have an influence on rural entrepreneurial activities? If so, how? These issues deserve research.

Based on these premises, this paper takes China as an example in a discussing whether and how environments at the scale of community affect rural entrepreneurial activities, and applies the concept of "mixed embeddedness" from the social, institutional, and economic dimensions. This paper not only gives a response to the contextualization issue that the entrepreneurial research in China has overlooked, but also answers the question raised by Pike et al. (2000) [11], namely, "Who is embedded in what?" Moreover, it aims to provide a decision-making basis for entrepreneurial policy incentives synergizing with local elements or conditions to boost the rural revitalization of China.

The reminder of this paper is constructed as follows. The second section contains a literature review on farmer entrepreneurship from the perspective of mixed embeddedness, and raises some hypotheses. The third section introduces the data sources, valid sample characteristics, and variable selection, and the fourth section uses a binary logistic regression (BLR) model for data processing, and analyzes the results. The last section outlines the contributions of this research, draws some conclusions, and points out some limitations.

\section{Literature Review and Hypotheses}

\subsection{Rural Entrepreneurship and Communities}

Entrepreneurship can stimulate the vitality of local economies and improve economic productivity [3], and it is also supported by the local social, economic, political, and cultural environments $[12,13]$. The latter factor also affects an individual's entrepreneurial decision making and their entrepreneurial performance. In terms of entrepreneurship, rural areas have a special nature and resources that are different from those of cities [5], including the natural environment, landscape, and agriculture, and these are sources of entrepreneurial capital that cannot be ignored. Modern rural entrepreneurship often relies on the natural and cultural heritage of the territory and combines the primary industry with the tertiary industry, such as agricultural tourism and leisure tourism [1]. In the 1950s, China's rural areas were vast in scope and contributed greatly to the rural economy. After the reform and opening up, some farmers began to engage in non-agricultural production activities, 
and entrepreneurial activities developed rapidly, which was directly reflected in the large increase in the number of private enterprises [14].

The concept of "community" has been introduced into rural entrepreneurship research. A strand of literature regards the community as a spatial vessel for entrepreneurial activities, and focuses on the individual characteristics of entrepreneurs, which weakens the potential influence of the community on entrepreneurial activities [15]. Another strand of literature has introduced the community concept into the institutional interpretation of rural entrepreneurship, and this research includes the following three main categories. First, the rural community is considered as the local context upon which entrepreneurial activities rely $[16,17]$. As this viewpoint focuses on the locality, the connotation of the community it describes is complex and comprehensive, including natural resources, as well as social, economic, cultural, institutional, and other aspects. Second, the interpretation focuses on the connection and cooperation among enterprises within the community and attaches importance to the analysis of corporate networks within the community. This viewpoint states that the community can promote the connection between networks and territories, and that there are persistent and wide geographical connections among the members of the community [18]. Thus, the community plays a role in promoting the agglomeration of entrepreneurial activities [19]. Third, this interpretation pays attention to the organizational role of the community, and incorporates it into the local environment as an organization with economic goals and market demands. This organizational role is considered to be the reason why the community stimulates entrepreneurship [20]. For example, according to Richard et al. (2018) [21], in rural communities with a high level of social capital, they have become accustomed to solving problems in a collective way, which makes the community the ideal environment for social enterprises to develop. These characteristics are unique to the village, and are different from the urban in terms of entrepreneurial activities.

Chinese rural communities emphasize the participation of villagers [22], and this participation makes rural communities the basic unit of rural social service and governance [23]. During China's institutional reform from a planned economy to a market economy, rural entrepreneurial activities promoted the revolutionary changes in regional development [24]. In the 1980s and 1990s, China's rural economies presented rapid growth and momentum, and non-agricultural activities in rural areas began to increasingly emerge, mainly thanks to private micro-enterprises [25] and collective enterprises [14]; the latter are often referred to as township and village enterprises (TVEs), which are officially owned by the community and actually controlled by managers via a management responsibility contract [24,25]. Individuals, collective agencies, governments, and the market have become the elements that interrelate and constrain each other in the rural economy. In this context, the community links the multi-faceted interests and is of some unique value in China's rural economic development [24]. However, the international literature on entrepreneurship in China has relatively little discussion concerning the background of rural communities.

\subsection{Mixed Embeddedness and Entrepreneurship in Rural Communities}

The embeddedness concept was proposed by the economic sociologist Polanyi (1944), and has been used to demonstrate that the economic activities are embedded in social relationships [26]. Later, Granovetter (1985) revitalized the concept by distinguishing relational embeddedness from structural embeddedness [27]. The former refers to the embedding nature of economic behavior in interpersonal relationships, while the latter refers to the influence of the network structure embedded by individuals. Zukin and DiMaggio (1990) identified four types of embeddedness, i.e., cognitive, cultural, structural, and political embeddedness [28]. The concept of "embeddedness" that was initially introduced by the research on international immigration and entrepreneurship focuses on the social embeddedness [29], which refers to the entrepreneurial activities are embedded in ethnic relations and immigrant entrepreneurs relying on immigrant communities [30]. Kloosterman proposed the concept of mixed embeddedness, in which the micro level of individual entrepreneurs and their resources is combined with the intermediate level of the local opportunity structure, and their 
entrepreneurial activities are placed within a broader institutional context to discuss the multiple embeddedness of immigrant entrepreneurial activities in the social, economic, and institutional environments of host countries [29]. The mixed embeddedness framework has gradually been applied to women's entrepreneurship [31,32], as well as urban and rural migrant entrepreneurship [33], among others, to discuss the impact of local socio-cultural, economic, and institutional environments on the entrepreneurship of special groups. It is believed that there are some similarities in the characteristics between rural entrepreneurship and immigrant entrepreneurship for the round-trip migration in rural China [34]. Therefore, this paper uses the concept of mixed embeddedness to analyze the impact of the rural community environment on the farmers' entrepreneurial activities.

\subsubsection{Social Embeddedness and Farmer Entrepreneurship}

Social embeddedness emphasizes the influence of social relations and network structure on people's economic activities, and it plays a key role in individual entrepreneurial activities [21]. The trust-based "relationship" or "relationship capital" provides the resources (such as employees, venture capital, and production licenses) and business environment and great entrepreneurial support for start-ups $[35,36]$. It also helps entrepreneurs cognize new consumers through establishing a good reputation [37,38], and influences their ability to utilize economic resources [12] and make their judgment on potential markets [38].

Local social networks are also of importance to rural entrepreneurial activities [35]. The economic development in rural areas often faces specific challenges, such as the distance from consumers and financial markets, the higher infrastructure costs, low population density, and high rate of emigration, and the difficulty to search for or acquire skilled labor. Social networks, community cohesion, and interpersonal trust are beneficial to overcome these challenges, and thus facilitate farmers in starting up new businesses in rural areas [39]. In the rural communities of China, the diversity-orderly pattern is a traditional social structure, which means that an individual's social network is restricted by various factors (such as blood relationship, geographical closeness, wealth level, political status, educational level, etc.), and blood and geographical relationships are fundamental. The stronger these factors are, the larger the network will be, which further affects one's social and economic life [40]. It is generally considered that kinship plays a long-term role, and family members appear in the social networks of entrepreneurs at all stages; especially in the early stages of entrepreneurship, the connection to family members is directly related to the success or failure of the entrepreneurship [41]. However, little attention has been paid to the importance of neighborhood relationships, which are a kind of geographical relationship.

Neighborhood relationships, as a localized source of social capital, are a key factor in maintaining the survival and development of a community [42]. Such relationships are not as strong as kinship within a community, but they are a kind of weak tie due to the geographical proximity and frequent face-to-face contact. It is relatively stronger and more beneficial than blood relationships that are far from the community in terms of farmer entrepreneurship; as a Chinese ancient saying says, "a good neighbor is better than a brother far off". Depending on such relationships, farmers can get some financial and social support, and enjoy sharing knowledge, as the industrial cluster literature emphasizes [43]. Furthermore, neighborhood characteristics affect the perceptions of community residents to the outside world. According to Kloosterman (1999) [29], the informational resources of neighborhood economic activities have an impact on the employment and entrepreneurial choices of community residents, and will lead start-up enterprises into specific industries, even forming community-based business groups. That implies that the quality of neighborhood relationships as a whole in rural communities is important for rural entrepreneurship, which is the authors' concern in this article.

Therefore, we propose, 
Hypothesis 1a. The better the neighborhood relationships in the rural community are, the higher level of farmer entrepreneurship will be.

The networks of entrepreneurs are constantly changing during the different stages of entrepreneurship [41], which means that other kinds of relationships besides strong ties, such as blood-based relationships and neighborhood relationships, should be examined in the research on farmer entrepreneurship. Actually, the importance of weak ties has been overlooked. According to Granovetter (1973) [44], the blood and neighborhood relationships within a community as strong ties mean a homogeneity of resources and a low level of accessibility to some key resources and factors, while weak ties have advantages in obtaining heterogeneous resources. Since China's reforming and opening up in the late 1970s, a number of farmers have floated into the cities, and urban investors have sought business opportunities in the countryside, which has caused the social structure to change greatly in rural areas.

Kalantaridis (2010) [35] believed that population mobility has a certain effect on reshaping local social networks, thus affecting rural entrepreneurial activities. On the one hand, population mobility promotes the links to new opportunities and increases weak ties, and thus it enables the residents within the community to access rural resources and social networks; on the other hand, migrants can provide new sources of demands for products and services from rural areas, and especially, local farmers migrating to cities are supposed to establish a linkage with cities, thus bringing new market opportunities, besides sending financial capital and professional skills back home. The authors wonder if the population mobility in rural China, as a factor of social context of rural communities and a source of new weak ties for farmers, affects farmer entrepreneurship in China.

Therefore, we propose,

Hypothesis $\mathbf{1 b}$. The higher the population mobility in rural communities, the higher level of farmer entrepreneurship will be.

\subsubsection{Institutional Embeddedness and Farmer Entrepreneurship}

It is recognized that institutions play a particularly important role in entrepreneurship in emerging markets and transitional economies, ranging from entrepreneurs' ability to access resources and their behaviors, the reform influence of the socialist republic on the corporate and market economies, and the nature, rhythm, and degree of entrepreneurship [45]. Scott (2001) [46] divided the institution into three systems: regulative, normative, and cultural-cognitive. The regulative system represents the standard norms such as laws issued by authorities, and can be viewed as formal institutions; the normative system is based on informal network ties and commitments; and the cultural-cognitive system refers to "the shared conceptions that constitute the nature of social reality and the frames through which meaning is made", and the latter two categories can be viewed as informal institutions.

Institutions develop the rules of economic activities, which reduce transaction costs and risks, increase individual ability to access entrepreneurial resources, and create certain limitations [47]. Local governments can develop economic rules by setting up departments, making policies such as providing loan/subsidies programs and entrepreneurial resources, and create appropriate business environments with easy access to infrastructure and public services [47]. Entrepreneurs can overcome limited personal trust through institutional embeddedness and establish cooperation with more economic entities [4]. They can also improve their reputation and obtain preferential policies and market information through embeddedness in local government departments and industry organizations [48]. However, a few entrepreneurs can not only handle institutional rules, but also establish social relations with government officials, which facilitates their improved embeddedness in the institutional environment [49]. Furthermore, in some cases, the incentive policies of entrepreneurship were not necessarily desirable [50]. These partly explain why the policies 
of the Chinese government have not yet effectively promoted entrepreneurial activities, as the Global Entrepreneurship Monitor (GEM) has found [51], and also indicate whether or not these encouragements are easy for farmers to access is an issue deserving attention.

In recent years, local governments have put forward encouragement policies as a response to the Chinese central government's call for "mass entrepreneurship and innovation", and established rural entrepreneurship and innovation parks as physical and mental supports in rural areas, especially for the purpose of attracting farmers returning home [52]. Moreover, in China, a large proportion of entrepreneurs tend to choose the necessity-motivated entrepreneurship, regarding entrepreneurship as a choice for obtaining the basic conditions for survival, instead of opportunity-motivated entrepreneurship, regarding entrepreneurship as a choice for seeking business success [51]. Therefore, local formal institutions, including income subsidies for rural households, may have an impact on farmers' entrepreneurship. It is still unclear whether these rural institutional services and facilities are effective, which is an area that deserves research.

Therefore, we propose,

Hypothesis 2a. The more that encouragements from local formal institutions are available, the higher the level of farmer entrepreneurship will be.

The importance of various informal institutions to entrepreneurship, such as the local traditions, customs, social norms, cultures, and unwritten code of conduct, has been also recognized [3,53]. If a region upholds the values of entrepreneurialism, the burgeoning entrepreneurial climate stimulates new business start-ups and the regional economic growth [54]. Lyon and West (2011) [55] also found that the entrepreneurship in a region generally exhibits a homogenous trend for the shared cultural values of the local immigrant community. The increasing entrepreneurial spirit will also drive reforms and the legalization of the informal institutions, so as to further influence the formal institutions [4]. That is also what Li et al. (2012) [14] viewed; namely, there is an endogenous relationship between formal institutions and regional entrepreneurial spirit.

Besides the concerns about local traditional informal institutions mentioned above, it is argued that community-based enterprises affect the local entrepreneurial spirit regarding their greater attention to collective interests and sustainable development $[17,56]$. Such enterprises have both social and economic purposes. They can achieve a balance between individuals and institutions, enlighten individual entrepreneurial activities, and produce certain beneficial by-products of individual entrepreneurship and family entrepreneurship [16]. In China, communities are supposed to be a means of cultivating the entrepreneurial spirit, and are expected to encourage entrepreneurship through the construction of informal systems, such as the orientation of culture and values [53]. Actually, community-based enterprises, such as TVEs in some areas mentioned before, have brought about a spin-off of firms, which was beneficial to improving the local informal institutional environment for entrepreneurship at the rural community level [14]. However, it is still unclear whether or not community-based enterprises generally have an effect on local informal institutions, and further on farmer entrepreneurship in China.

Therefore, we propose,

Hypothesis $\mathbf{2 b}$. The more encouragements from community-based enterprises are available, the higher the level of farmer entrepreneurship will be.

\subsubsection{Opportunity Structure and Farmer Entrepreneurship}

In the view of Kloosterman (1999) [29], an appropriate context for immigrant entrepreneurship also includes the political and economic structure of the market. For immigrant entrepreneurs, the opportunity structure is essentially a barrier to entering the mainstream market. Due to a lack of resources (such as human and financial capital), and their status as ethnic minorities, immigrant 
entrepreneurs only have a few "residual cracks" [57]. Farmer choose villages as their location of entrepreneurial activities due to the market opportunity, natural resources, or lower cost in the countryside, or difficulties entering urban areas. This article focuses on opportunities for farmer entrepreneurship rather than constrains (from the urban areas).

It was generally considered that natural resources in the countryside, such as farmland, climate, topography, etc., provided the opportunity to utilize these resources through setting up a firm [5]. However, in the rural areas of Wenzhou, China, the unfavorable conditions, including the large population and lack of farmland, forced the local farmers to transform from relying on agricultural production to industrial production by the establishment of their family-owned factories, thus meeting their actual livelihood needs. That case shows that rural resources are not an indispensable factor affecting entrepreneurial activities, and that their relationship with entrepreneurship opportunities is not unique. Also, for rural communities, entrepreneurial ideas generally stem from community members' demand [21]. That means that the demand-related social and economic attributes of rural communities, such as population size and household income level, create market opportunities for farmers to start businesses, while the employed population provides important labor resources on which local enterprises rely [58]. It also proves that rural communities are particularly vulnerable to demographic changes [59]. Furthermore, the market opportunities within the community also depend on both the community's original industrial organization, which is mainly represented by the degree of division, cooperation, and networking among various agricultural sectors, as well as between agricultural and non-agricultural industries. The vertical network belongs to the local village, and it links the rural resources with the agricultural sector, as well as the natural resources with manufacturing sectors. The horizontal network is a distributed network that links the rural space with the more popular non-agricultural economy, thereby achieving innovation and learning. The networks, especially the horizontal networks, promote the innovation and development of rural areas [60]. Since entrepreneurs usually fail to obtain financial support from formal institutions (such as banks), they need to obtain economic resources from local economic entities by networking with them [12] outside of their household [25,61]. Additionally, according to Krugman et al. (1991) [62], local enterprises obtain substantial benefits from industrial clusters, and some evidence shows that the entrepreneurship rate in areas where small businesses conglomerate is usually higher [43]. The factors mentioned above affect the internal market opportunities of entrepreneurship in rural communities.

Therefore, we propose,

Hypothesis 3a. The more market opportunities that rural communities have, the higher the level of farmer entrepreneurship will be.

Greenberg et al. (2018) [6] considered external networks, as well as local networks, to be of important value to rural entrepreneurship in that they realize the accumulation of resources and the development of the market through internal and external transactions and exchanges. The authors were concerned with the external linkage of rural communities to their upper central towns or cities, which are supposed to be the nearest external markets with the most frequent economic transactions of products. Such towns or cities are considered to provide access to the markets of central cities and opportunities of non-agricultural production [63-65], thus both probably influencing factors for farmer entrepreneurship. However, whether or not opportunities based on such external relationships between urban and rural areas is related to farmer entrepreneurship remains uninvestigated.

Therefore, we propose,

Hypothesis $3 \mathbf{b}$. The more opportunities that rural communities have based on the external linkages with their upper central towns or cities, the higher the level of farmer entrepreneurship will be. 


\section{Data Source, Sample Characteristics, and Variable Selection}

\subsection{Data Source}

Except for regional economic data from the China Statistical Yearbook 2014, all of the other data related to the individual, family, and communities are based on the China Family Panel Studies (CFPS) 2014 tracking survey database from the Open Research Data Platform of Peking University [66].

The CFPS survey officially occurred in 2010, and a follow-up visit was conducted every two years. The survey used three-level stratified sampling to emphasize its geographical representation. The multi-stage equal probability sample was extracted with the implicit stratification method, thus reflecting the differences among the structure of administrative divisions, cities and countries, and households. In the survey, the urban-rural attribute of the community is defined by the nature of the grassroots organizations. A community coordinated by a village committee is classified as a rural area; it is classified as an urban area if coordinated by a neighborhood committee. The same questionnaire was used in both urban and rural areas, and only a small portion of questions indicating urban-rural features (such as cultivated land resources and migrant workers) were designed for one of the two groups.

This article uses the data of the CFPS 2014 follow-up survey. A total of 621 urban and rural communities were involved in this survey, with 13,946 urban and rural families from 29 provinces/cities/autonomous regions. The province distribution is shown in Figure 1. The sample from Inner Mongolia, Hainan, Ningxia, and Xinjiang were not put into use for their extremely small number of samples for the avoidance of possible interference, and 9092 rural samples (families) and 3855 urban samples remain.

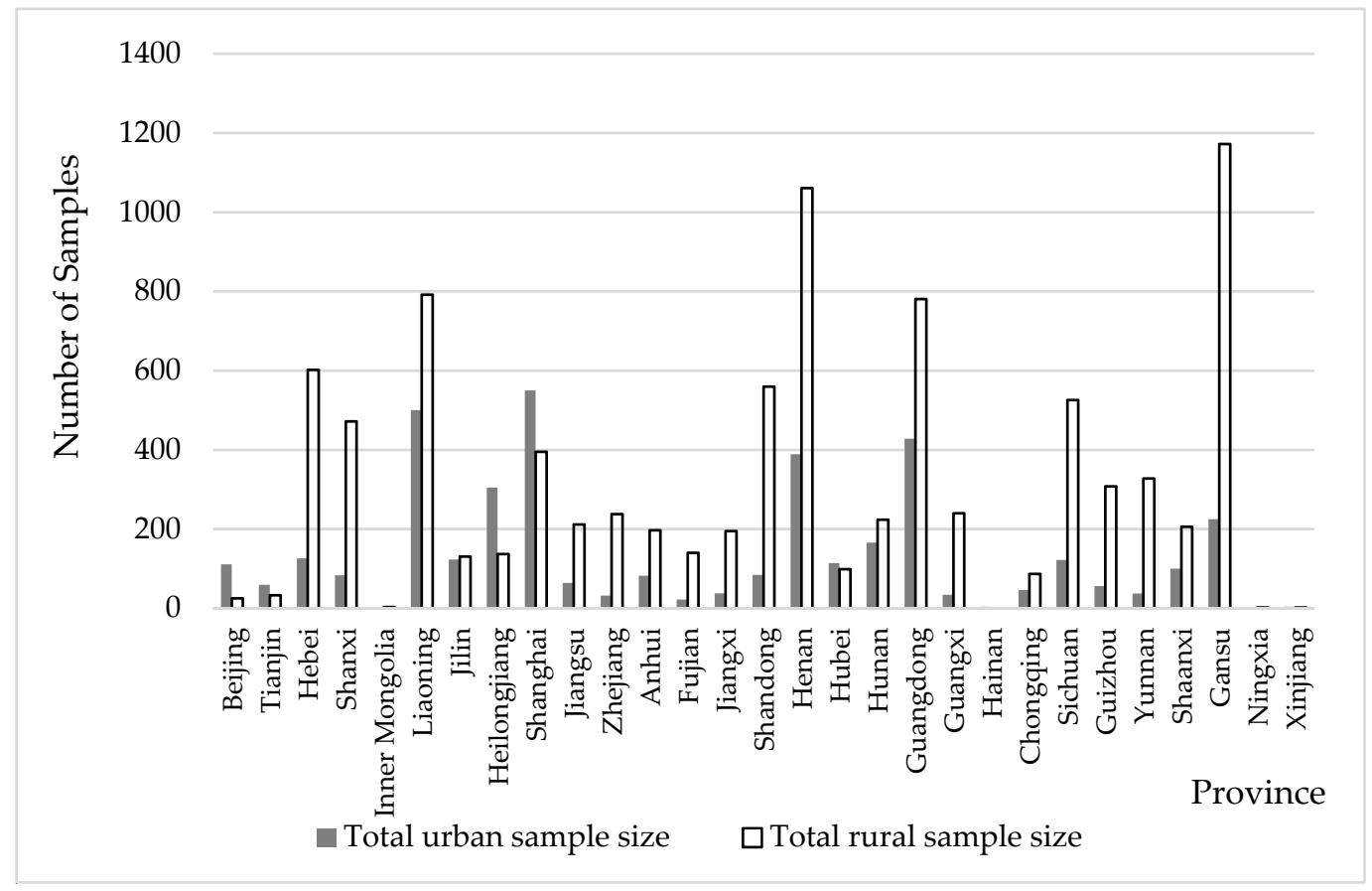

Figure 1. Statistics on the urban and rural sample size in the China Family Panel Studies (CFPS) 2014.

\subsection{Sample Characteristics}

A total of 5756 valid rural samples with effective data of the variable indicators in this research were selected, accounting for $63.3 \%$ of the total rural samples in the CFPS 2014 database. Among those valid rural samples, 456 belong to the self-employment group, accounting for $7.92 \%$ of the total valid samples. This proportion is approximate to the entrepreneurship rate of the total 9092 samples $(8.01 \%)$, which means the valid rural samples are generally representative of the total. The basic characteristics 
of the valid samples are shown in Table 1. Figure 2 shows the provincial distribution of the total rural samples in CFPS 2014, and that of the valid samples involved in this research. The two groups have a similarity in spatial structure, which also reflects that the valid samples have representative characteristics of the total rural samples.

Table 1. Basic characteristics of 5756 valid samples.

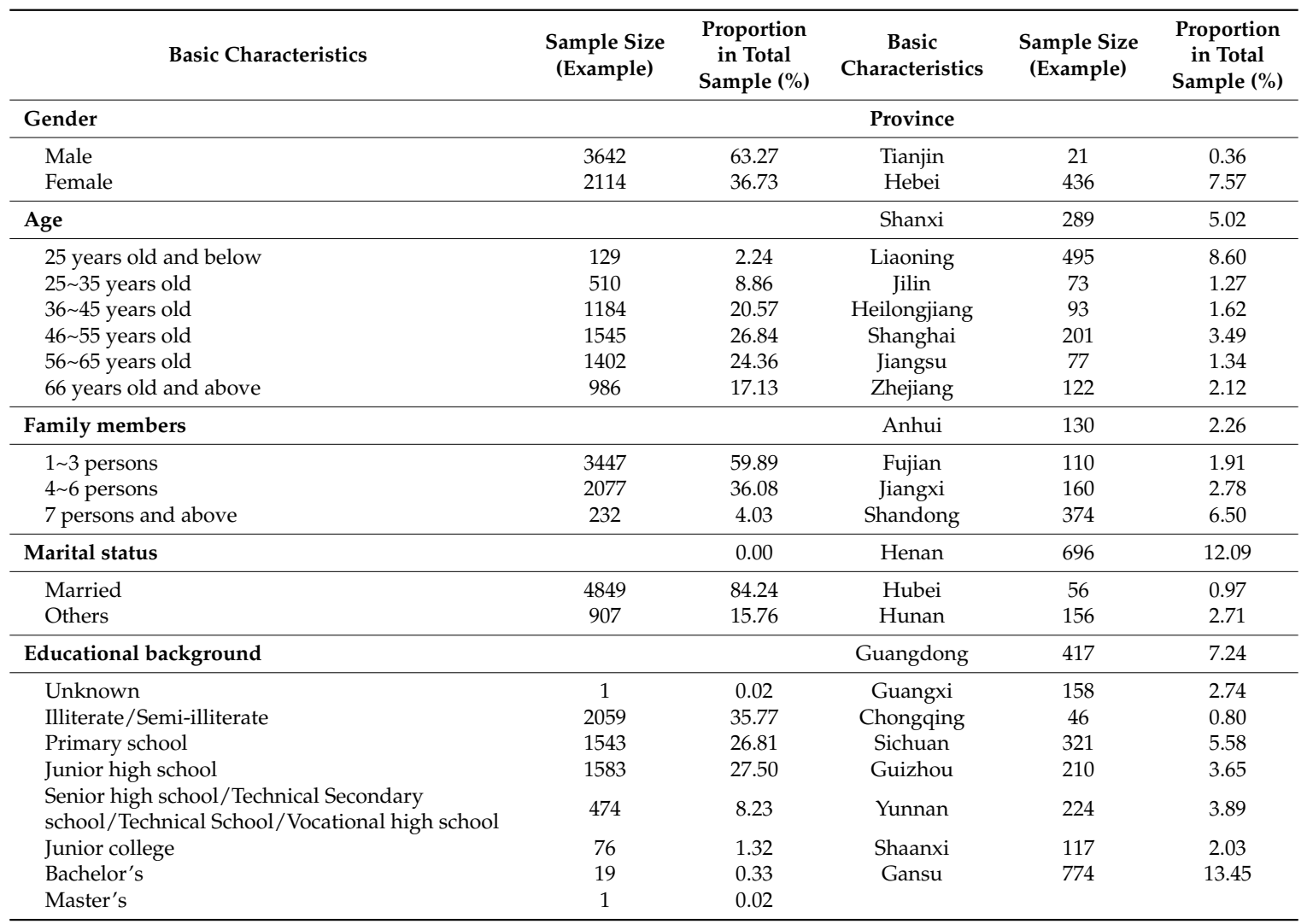

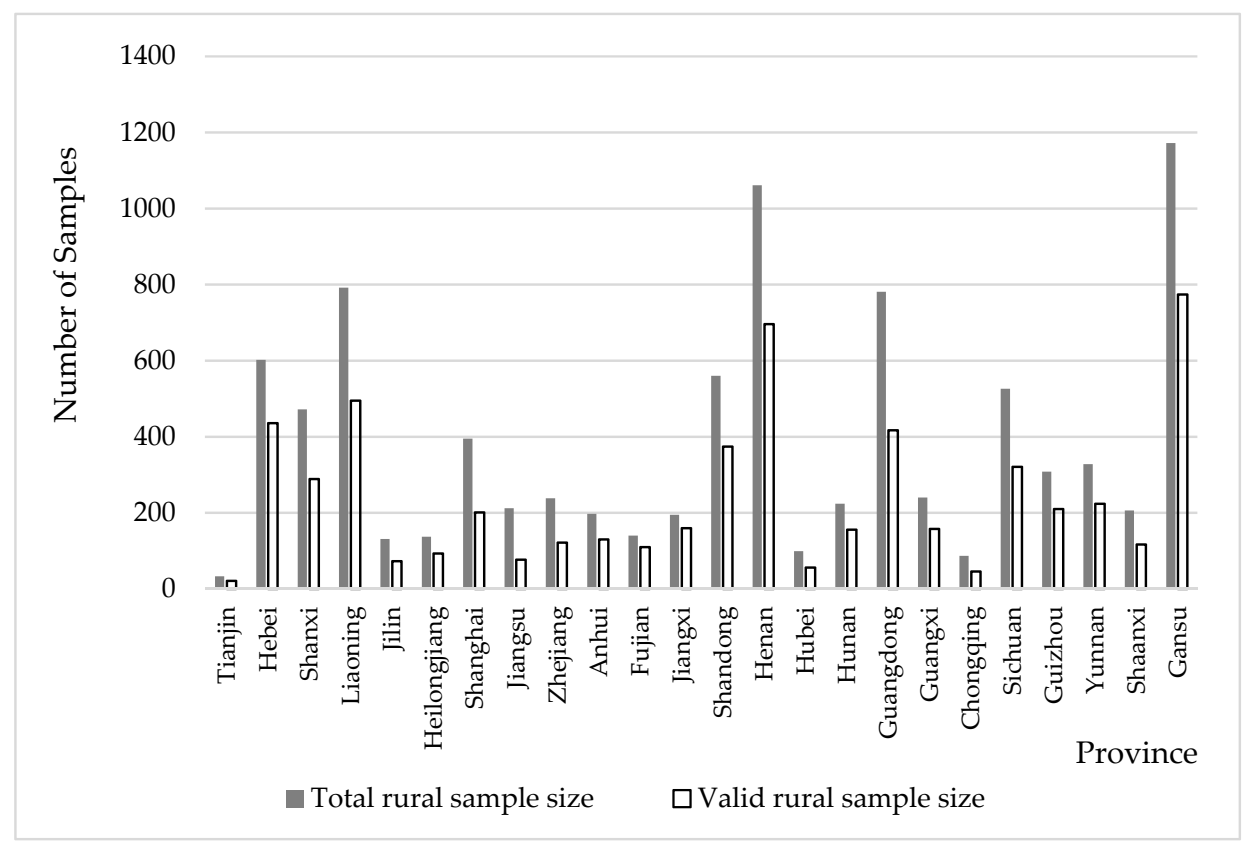

Figure 2. Distribution of the total rural samples and the valid samples by province. 


\subsection{Variable Selection}

According to the related literature $[67,68]$, individual entrepreneurship was selected as the dependent variable, and corresponds to the question "whether to engage in individual and private business" in the CFPS 2014 questionnaire. It is a dichotomous variable in this article.

Based on this database, this paper uses neighborhood relationship, kinship, and population mobility to characterize the social environment of the community. Considering the regulatory nature of institutional embeddedness, we choose the "subsistence allowance" system guarantee and the density of rural entrepreneurship and innovation parks to represent the formal institutions. The self-established enterprises in communities, the homogeneity of local residents, and the mental outlook of community members are selected as indicators of the informal systems related to farmer entrepreneurship in the community. The economic situation of the community, the economic activities of the population, the market size, the economic resource, the community location, and the infrastructure level are selected to characterize the local economic environment, which also represents local market opportunities. Besides, factors concerning personal attributes [69-71] and regional features [72-74] were also considered as control variables. The selection and interpretation of the indicators is shown in Table 2.

Before the model processing and analysis, the collinearity test for the samples is conducted. The results are shown in Table 3. The variance inflation factors (VIF) of all the variables are less than 2.000 , and there is no significant collinear issue between the independent variables. 
Table 2. Variable type, index selection, and its interpretation.

\begin{tabular}{|c|c|c|c|c|}
\hline Types of Variables & Category & Indicator & Variable Name & Variable Definitions \\
\hline Dependent variable & & Entrepreneurship [41] & entrepreneurship & Whether to engage in individual and private business exists: Yes $=1, \mathrm{No}=0$ \\
\hline \multirow{15}{*}{ Independent variables } & \multirow{3}{*}{$\begin{array}{l}\text { Social dimension of community } \\
\text { environment }\end{array}$} & Neighborhood harmony [29] & C_neighbor & Very tense $=1$, A little tense $=2$, General $=3$, Relatively harmonious $=4$, Very harmonious $=5$ \\
\hline & & Kinship [41] & C_kin & Contact frequency: More than once a month $=1,1-3$ times half a year $=2,1-2$ times a year $=3$, none $=4$ \\
\hline & & $\begin{array}{l}\text { Weak ties based on population } \\
\text { mobility [35] }\end{array}$ & C_mobility & $\begin{array}{l}\text { Proportion of temporary mobility population in total population of the community: } 0 \%=1,0-1.78 \%=2 \text {, } \\
\qquad 1.79-8.9 \%=3,9.0-30.0 \%=4,>30 \%=5\end{array}$ \\
\hline & \multirow{5}{*}{$\begin{array}{l}\text { Institutional dimension of } \\
\text { community environment }\end{array}$} & Institutional guarantee [41] & C_insti & Whether to implement subsistence allowance: Yes $=1$, No $=0$ \\
\hline & & Entrepreneurial policies [52] & C_entre_p & $\begin{array}{l}\text { Number of rural entrepreneurship and innovation parks per 10,000 non-urban population in the province: } \\
<0.00518=1,0.00518-0.01178=2,0.01179-0.01551=3,0.01552-0.02728=4,0.02729-0.005854=5\end{array}$ \\
\hline & & $\begin{array}{l}\text { Entrepreneurial atmosphere } \\
{[54,56]}\end{array}$ & C_entre_atmos & Whether the community has started self-established enterprises in the past three years: Yes $=1$, No $=0$ \\
\hline & & Homogeneity of residents & $\mathrm{C}_{-}$homo & Mixed-Quite similar: $1-7$ \\
\hline & & Mental outlook of members & C_mental & Dispirited-Spirited: $1-7$ \\
\hline & \multirow{7}{*}{$\begin{array}{l}\text { Economic dimensions of } \\
\text { community environment }\end{array}$} & Economic situation [59] & C_eco & Very poor-Very rich: $1-7$ \\
\hline & & $\begin{array}{l}\text { Economic activities of } \\
\text { community population [35] }\end{array}$ & C_eco_act & $\begin{array}{l}\text { Proportion of migrant workers in total population of the community: }<10 \%=1,10-27 \%=2,28-45 \%=3 \text {, } \\
\qquad 46-65 \%=4,66-90 \%=5\end{array}$ \\
\hline & & Economic resource [5] & C_resource & Area of farmland owned $/ \mathrm{mu}: \leq 750=1,751-1500=2,1501-3100=3,3101-5400=4, \geq 5400=5$ \\
\hline & & Market size [59] & C_market & Population grade: $<1000=1,1000-1700=2,1701-2310=3,2311-3760=4,>3760=5$ \\
\hline & & Community location $[63,65]$ & C_trans_town & Distance from the nearest town $/$ li: $0-1=1,1.01-5=2,5.01-20=3,20.01-50=4,>50=5$ \\
\hline & & & $\mathrm{C}_{-}$trans_city & $\begin{array}{l}\text { Distance from the nearest provincial capital } / \text { li: } 0-20=1,20.01-80=2,80.01-400=3,400.01-1000=4, \\
\qquad>1000=5\end{array}$ \\
\hline & & Infrastructure level [64] & C_infrastructure & $\begin{array}{l}\text { The main type of fuel most families in the community used for cooking: Firewood } / \text { coal } / \text { canned } \\
\text { gas/liquefied gas }=0 \text {, natural gas } / \text { pipeline gas/solar } / \text { bioga / electricity }=1\end{array}$ \\
\hline \multirow{9}{*}{ Control variables } & \multirow{8}{*}{ Personal attributes [69-71] } & Age & age & $>18$ \\
\hline & & Gender & gender & Male $=1$, Female $=0$ \\
\hline & & Education & edu & $\begin{array}{c}\text { Illiterate } / \text { semi-literate }=1 \text {, elementary school }=2 \text {, junior high school }=3 \text {, high school } / \text { secondary } \\
\text { school } / \text { technical school } / \text { vocational school }=4 \text {, junior college }=5 \text {, bachelor }=6 \text {, master }=7 \text {, doctor }=8\end{array}$ \\
\hline & & Work experience & everwork & Once worked $=1$, None $=0$ \\
\hline & & Political identity & party & Party member $=1$, Others $=0$ \\
\hline & & Marital status & marriage & Married $=1$, Others $=0$ \\
\hline & & Family member scale & F_scale & Family member number \\
\hline & & Family economic status & F_eco & Any property in addition to the house lived in now: Yes $=1, \mathrm{No}=0$ \\
\hline & $\begin{array}{l}\text { Regional economic environment } \\
{[72-74]}\end{array}$ & Economic development level & R_eco & $\begin{aligned} 2013 \text { Provincial GDP/100million yuan: }<12,650=1,12,650-14,380=2,14,380.01-22,000=3, \\
22,000.01-29,000=4,>29,000=5\end{aligned}$ \\
\hline
\end{tabular}

Notes: The regional environmental indicators come from the China Statistical Yearbook 2014. GDP: gross domestic product. 
Table 3. Collinear statistics. VIF: variance inflation factor.

\begin{tabular}{ccccc}
\hline & $\mathbf{t}$ & Sig. & \multicolumn{2}{c}{ Collinear Statistics } \\
\cline { 5 - 5 } & & & Tolerance & VIF \\
\hline constant & 2.236 & 0.025 & & \\
C_neighbor & 1.984 & 0.047 & 0.942 & 1.061 \\
C_kin & -0.622 & 0.534 & 0.929 & 1.077 \\
C_mobility & 1.695 & 0.090 & 0.907 & 1.103 \\
C_insti & -0.602 & 0.547 & 0.943 & 1.060 \\
C_entre_p & -1.767 & 0.077 & 0.899 & 1.113 \\
C_entre_atmos & 5.666 & 0.000 & 0.978 & 1.023 \\
C_homo & 0.128 & 0.899 & 0.618 & 1.619 \\
C_mental & -0.961 & 0.337 & 0.517 & 1.935 \\
C_eco & 2.413 & 0.016 & 0.612 & 1.633 \\
C_eco_act & -1.216 & 0.224 & 0.929 & 1.076 \\
C_resource & -0.612 & 0.540 & 0.864 & 1.157 \\
C_market & -1.399 & 0.162 & 0.883 & 1.132 \\
C_trans_town & -3.278 & 0.001 & 0.883 & 1.132 \\
C_trans_city & -1.218 & 0.223 & 0.905 & 1.105 \\
C_infrastructure & 1.960 & 0.050 & 0.952 & 1.050 \\
age & -7.940 & 0.000 & 0.769 & 1.300 \\
gender & 2.816 & 0.005 & 0.908 & 1.102 \\
edu & 4.630 & 0.000 & 0.800 & 1.250 \\
everwork & 2.021 & 0.043 & 0.889 & 1.125 \\
party & 0.132 & 0.895 & 0.909 & 1.100 \\
marriage & -0.518 & 0.605 & 0.908 & 1.101 \\
F_scale & 4.460 & 0.000 & 0.893 & 1.120 \\
F_eco & 9.517 & 0.000 & 0.969 & 1.032 \\
R_eco & 2.945 & 0.003 & 0.872 & 1.147 \\
\hline
\end{tabular}

\section{Research Methods and Analysis of Results}

\subsection{Research Methods}

Logistic regression is a kind of generalized linear regression analysis model, which is often used in data mining, economic forecasting, and other fields [75]. Binary logistic regression (BLR) is a kind of logistic regression, and its dependent variable has only two values, i.e., "occur" or "not occur", while its independent variables can be either continuous or classified [76]. The rural entrepreneurial indicator $(\mathrm{Y})$ "whether to engage in individual and private business" is consistent with the $0-1$ value characteristics of this regression model, and the independent variables include the 24 variables selected in Table 2 based on the above analysis. The BLR model is shown below, and the functional form of this model is a cumulative logistic probability function and is shown in Equation (1), while the estimated formula is shown in Equation (2):

$$
\begin{aligned}
& \mathrm{P}\left(\mathrm{Y}=1 \mid \mathrm{X}=\mathrm{X}_{i}, i=1,2, \ldots, m\right)=\frac{1}{1+e^{-\left(\alpha+\sum_{i=1}^{m} \beta_{i} \mathrm{X}_{i}+\mu\right)}} \\
& \operatorname{logit} \mathrm{P}\left(\mathrm{Y}=1 \mid \mathrm{X}=\mathrm{x}_{i}, i=1,2, \ldots, m\right)=\ln \left(\frac{P}{1-P}\right)=\alpha+\sum_{i=1}^{m} \beta_{i} \mathrm{X}_{i}+\mu
\end{aligned}
$$

Wherein, $i$ indicates the $i$ th variable, the overall probability of $\mathrm{Y}=1$ is $P, \beta_{i}$ stands for the coefficient of the $i$ th variable to be estimated, $X_{i}$ stands for the explanatory variable, including the variables listed in Table $2, \alpha$ is a constant, and $\mu$ stands for the error term. If the dependent variable $(Y)$ is proportional to a factor, it is believed that under the influence of this factor, $\mathrm{Y}$ is more likely to be one; that is, the possibility of entrepreneurship is greater [76]. The Hosmer and Lemeshow (H\&L) test and prediction accuracy could be used to test the fitting effect of the model [77]. If the H\&L test $>0.05$ and prediction accuracy $>0.85$, that indicates a relatively good model fit and accurate prediction. 


\subsection{Analysis of Results}

The results of the rural entrepreneurship model using the binary logistic regression and the stepwise culling method are shown in Table 4.

Table 4. Results of the regression model with the stepwise culling method.

\begin{tabular}{|c|c|c|c|c|c|c|}
\hline & \multicolumn{2}{|c|}{ Model I } & \multicolumn{2}{|c|}{ Model II } & \multicolumn{2}{|c|}{ Model III (Urban) } \\
\hline & B & OR & B & OR & B & OR \\
\hline C_neighbor & $0.115 *$ & 1.122 & $0.113 *$ & 1.120 & -0.031 & 0.969 \\
\hline C_kin & -0.073 & 0.929 & -0.073 & 0.930 & -0.109 & 0.897 \\
\hline C_mobility & $0.063 *$ & 1.065 & $0.066^{*}$ & 1.069 & -0.105 & 0.901 \\
\hline C_insti & -0.106 & 0.899 & - & - & 0.074 & 1.077 \\
\hline C_entre_p & $-0.087^{* *}$ & 0.916 & $-0.083 * *$ & 0.920 & $-0.149^{* *}$ & 0.861 \\
\hline C_entre_atmos & $2.221 * * *$ & 9.220 & $2.220 * * *$ & 9.207 & 0.633 & 1.884 \\
\hline C_ homo & 0.019 & 1.019 & - & - & -0.025 & 0.976 \\
\hline C_mental & -0.068 & 0.934 & -0.059 & 0.942 & $-0.189 * *$ & 0.828 \\
\hline C_eco & $0.125 * * *$ & 1.133 & $0.128 * * *$ & 1.137 & $0.212^{* *}$ & 1.236 \\
\hline C_eco_act & -0.056 & 0.946 & -0.056 & 0.946 & - & - \\
\hline C_resource & -0.022 & 0.979 & - & - & - & - \\
\hline C_market & -0.130 & 0.878 & -0.140 & 0.869 & 0.060 & 1.062 \\
\hline C_trans_town & $-0.217^{* * *}$ & 0.805 & $-0.216^{* * *}$ & 0.805 & - & - \\
\hline$\overline{\mathrm{C}}$ trans city & -0.082 & 0.921 & -0.080 & 0.923 & - & - \\
\hline C_infrastructure & $0.217 *$ & 1.242 & $0.209 *$ & 1.232 & 0.069 & 1.072 \\
\hline age & $-0.039 * * *$ & 0.962 & $-0.039^{* * *}$ & 0.962 & $-0.054 * * *$ & 0.947 \\
\hline gender & $0.333^{* * *}$ & 1.395 & $0.333^{* * *}$ & 1.396 & $0.320 * *$ & 1.378 \\
\hline edu & $0.224 * * *$ & 1.252 & $0.227^{* * *}$ & 1.255 & $-0.189^{* * *}$ & 0.828 \\
\hline everwork & $0.563 * * *$ & 1.756 & $0.557 * * *$ & 1.746 & $0.822 * * *$ & 2.275 \\
\hline party & 0.027 & 1.028 & - & - & $-0.472 * *$ & 0.624 \\
\hline marriage & 0.180 & 1.198 & 0.180 & 1.198 & $-0.838^{* *}$ & 0.432 \\
\hline F_scale & $0.130 * * *$ & 1.139 & $0.132 * * *$ & 1.141 & $0.176^{* * *}$ & 1.193 \\
\hline F_eco & $1.025^{* * *}$ & 2.788 & $1.028^{* * *}$ & 2.795 & $0.466^{* * *}$ & 1.594 \\
\hline R_eco & $0.093^{* * *}$ & 1.097 & $0.094^{* * *}$ & 1.099 & -0.028 & 0.972 \\
\hline constant & $-2.344^{* * *}$ & 0.096 & $-2.508^{* * *}$ & 0.081 & $0.535^{* * *}$ & 1.707 \\
\hline Accuracy of the model's prediction & \multirow{2}{*}{\multicolumn{2}{|c|}{$\begin{array}{l}0.922 \\
0.235\end{array}$}} & \multicolumn{2}{|c|}{0.922} & \multicolumn{2}{|c|}{0.876} \\
\hline H\&L test & & & \multicolumn{2}{|c|}{0.498} & \multicolumn{2}{|c|}{0.258} \\
\hline
\end{tabular}

Notes: (1) B represents the estimation coefficient of the variable; (2) OR represents the odds ratio; $(3)^{* * *}$,**, and * respectively indicate significance at levels of $0.01,0.05$, and 0.1 . H\&L: Hosmer and Lemeshow.

The models (I) and (II) are the results of rural samples using the stepwise culling regression, with (I) being the results of the first steps of all the entries, and (II) being the results with the highest prediction accuracy. The model (III) is the regression results of the urban samples. The accuracy of three models' prediction is higher than $85 \%$. Their significance levels for the H\&L test are all greater than 0.05 , and the model fits the sample well.

In model (I) and model (II), neighborhood harmony (C_neighbor) and weak ties based on population mobility (C_mobility) in the social dimension of the community environment, the entrepreneurial atmosphere (C_entre_atmos) in the institutional dimension of the community environment, as well as the economic situation (C_eco) and infrastructure level (C_infrastructure) in the economic dimension of the community environment, all have a positive correlation with entrepreneurship, indicating that the social, institutional, and economic dimensions of the community environment have positive effects on rural entrepreneurship. Thus, this result confirms our hypotheses. Kinship (C_kin), institutional guarantee (C_insti), homogeneity of residents (C_homo), mental outlook of members (C_mental), economic activities of community population (C_eco_act), economic resource (C_resource), market size (C_market), and community location to city (C_trans_city) did not pass the significance test.

Among all the variables in the community dimensions, the odds ratio (OR) of C_entre_atmos is the highest, and is much higher than other indicators. It is significantly positively correlated with 
entrepreneurship under the level of 0.01 . The $\mathrm{OR}$ value of $C_{-}$infrastructure is the second largest, and it is significantly positively correlated with entrepreneurship under the level of 0.1 . The OR value of C_eco is the third largest, and it is significantly positively correlated with entrepreneurship under the level of 0.01 . These results show that the entrepreneurial atmosphere in the informal institutional environment of rural communities plays an absolutely vital role in promoting rural entrepreneurship. The role of the institutional dimension of the community environment, especially the informal style, is stronger than those of the social and economic dimensions of the community environment.

In the social dimension of the community environment, only C_neighbor and C_mobility pass the significance test at the 0.1 level, and are positively correlated with entrepreneurship. It means that the more harmonious the neighborhood relationship, the higher the proportion of population mobility, and the more likely entrepreneurial activities will occur, which thus confirms Hypothesis 1a and Hypothesis $1 \mathrm{~b}$. Compared with blood relatives, the relationships formed through neighborhood and population mobility are weaker. Compared with the long-term stable and strong relationships, these weak ties have more advantages in entrepreneurial activities. The quality of neighborhood relationships plays a positive role in entrepreneurship, which is consistent with Hypothesis 1a. This also reflects the effect of "a distant relative is not as close as a neighbor". The information exchange and interaction happening in the process of population flow and harmonious neighborhood communication help trigger entrepreneurial activities. Population mobility affects the information sharing and social network structure in that it brings the information connection between the village and the external cities; as a result, the social relations within rural communities expand. This proximity will help with obtaining access to external markets, production, and other information, thereby stimulating entrepreneurial activities, and is thus consistent with Hypothesis 2a. The relationship networks cause information asymmetry, and the connection to elites can help start-ups gain more market information and a wider range of resources. At the same time, the correlation between C_kin and entrepreneurship is not significant, which means that the strong ties in rural areas, such as kinship, have been traditionally considered as being close, but have no significant effect in entrepreneurial activities. This indicates that compared to the blood relationships of relatives, the geographical proximity of the neighborhoods in the community has certain advantages in entrepreneurial activities. However, it should be noted that familial settlements are common in rural communities. Thus, it is undeniable that kinship plays a similar role in promoting entrepreneurship, along with neighborhood relationships.

In the institutional dimension of the community environment, only C_entre_atmos is significantly positively correlated with entrepreneurship, and among all the indicators, its correlation with entrepreneurship is the strongest. Thus, this result confirms Hypothesis $2 b$ : more available encouragement from informal institutions leads to the higher level of farmer entrepreneurship. Entrepreneurial policies (C_entre_p) are significantly negatively correlated with entrepreneurship, indicating that regional entrepreneurship policies haven't play a direct positive role in the community so far. C_insti, C_homo, and C_mental did not pass the significance test.

By running their own businesses, such as TVEs, community organizations have created a beneficial entrepreneurial atmosphere. Such an informal system plays a strong role in promoting rural entrepreneurship that is far higher than the other factors, and is thus consistent with Hypothesis $2 \mathrm{~b}$. In model (II), the OR of C_entre_atmos is 9.207, indicating that the informal institutional environment of community entrepreneurship has a decisive influence on rural entrepreneurship. Further data statistics showed that the entrepreneurship rate of communities in which there exist community self-established enterprises is as high as $12.91 \%$, which is higher than the average level $(8.01 \%)$. Community autonomy is a major feature of rural communities. With certain political functions, the community can further carry out production, operations, and service work through various orderly organizations formed by the village's self-governance. Community self-established enterprises are one approach playing an autonomous role in organizing resources and in carrying out economic activities. The informal orientation of entrepreneurship generated by this kind of autonomy stimulates individual 
entrepreneurial activities. The community self-established enterprise can guide and standardize entrepreneurial activities from the top to bottom, which is a special mode of local self-governance in entrepreneurship. Through public space and social capital connections, spontaneous individual entrepreneurial activities in the communities gather, forming bottom-up positive feedback. Due to the particular nature of this entrepreneurial form of starting up businesses, the self-established enterprise in the community may help the community residents learn new skills, understand entrepreneurial activities, and participate in all the entrepreneurial aspects of the community organization, which is conducive to independently carrying out entrepreneurial activities. The mental outlook of members reflects their life attitudes and the work enthusiasm of the members. It also to a certain extent reflects the vitality of the community, but does not show a direct connection with rural entrepreneurship.

The ownership rate in rural entrepreneurship and innovation parks does not have a positive influence on entrepreneurial activities, which is different from Hypothesis 2a. The construction of rural entrepreneurship and innovation parks has just started, and the utilization rate and the response of the local community are still not clear. In addition, entrepreneurial forms in those parks may be different from the types of individual entrepreneurship that we observed. Therefore, the entrepreneurship policy does not show positive feedback. The relationship between formal subsistence allowance systems and entrepreneurship is not significant. Most (98\%) of the sample communities implement the subsistence allowance policy, but there is no distinction between their implementation plans and strengths. The role of guarantee measures in entrepreneurial activities that have certain risks is not prominent. Although many rural entrepreneurial enterprises belong to the survival-based type, the guarantee policy does not involve support for this kind of entrepreneurship. The formal institution of entrepreneurship at the community level still needs to be explored.

C_eco and C_infrastructure in the economic dimension of community environment is significantly positively correlated with entrepreneurship, and community location to town (C_trans_town) is significantly negatively correlated with entrepreneurship. The positive effect of $C_{-}$eco confirms Hypothesis $3 \mathrm{a}$, which states that the market conditions of the community have a positive effect on entrepreneurship. The rural communities in China have certain economic functions. The overall economic level is the basis for organizing collective production and operation activities. A higher overall economic level of the community makes it more likely to organize economic activities such as self-employment, which in turn stimulates individual entrepreneurship. Moreover, the economic level of the community will influence the entrepreneurial choices of the local owners of financial capital through the consumption and labor markets. The positive effect of $C_{-}$infrastructure verifies Hypothesis $3 \mathrm{~b}$. Rural infrastructure construction is comprehensive, which reflects the improvement of the local modernization level through financial investment. The construction of natural gas pipelines and power grids also need good road traffic conditions. Convenient infrastructure conditions narrow the gap between urban and rural areas and improve the convenience of rural areas' contact with external resource, which is a positive stimulus to potential entrepreneurs. Additionally, C_resource, C_market, C_eco_act, and C_trans_city do not pass the significance test.

The geographical distance of the community from the central town has a negative impact on rural entrepreneurship. This result reflects the two-sided roles of the external market. For community residents, the town is both a sales market for entrepreneurial activities and a larger employment market. Table 5 further analyzes the distribution of the entrepreneurship samples and the entrepreneurship rates in "Distance from the nearest town". A "U"-shaped feature is found, and the community entrepreneurship rate presents a characteristic of high at both ends and low in the middle, according to the distance from the nearest town. Long and short distances will both benefit entrepreneurship. Being closer to the market town will allow people to achieve a timely understanding of the needs and changes of the market town, and carry out entrepreneurial activities according to market conditions. The community residents can engage in relatively high-profit entrepreneurial activities based on market needs. Far from the infrastructure and public services of the town, the long-distance community forms a relatively independent development system, in which entrepreneurial activities relying on local 
production and living demands emerge accordingly. The communities between 5-20 li do not have the advantages of short distance, nor do they have a long-distance independent system, and the entrepreneurship rate of this stage is the lowest (5.74\%). Therefore, a depression location forms for entrepreneurship.

Table 5. The sample's distance from the nearest town.

\begin{tabular}{cccccc}
\hline $\begin{array}{c}\text { Distance from } \\
\text { the Nearest } \\
\text { Town/Li }\end{array}$ & $\begin{array}{c}\text { Total Sample } \\
\text { Size }\end{array}$ & $\begin{array}{c}\text { Proportion in } \\
\text { Total Sample (\%) }\end{array}$ & $\begin{array}{c}\text { Entrepreneurship } \\
\text { Sample Size }\end{array}$ & $\begin{array}{c}\text { Proportion of the Total } \\
\text { Entrepreneurship } \\
\text { Sample (\%) }\end{array}$ & $\begin{array}{c}\text { Entrepreneurship } \\
\text { Rate of This Stage (\%) }\end{array}$ \\
\hline $0-1$ & 962 & 16.71 & 110 & 24.12 & 11.43 \\
$2-5$ & 1777 & 30.87 & 161 & 35.31 & 5.06 \\
$5-20$ & 2650 & 46.04 & 152 & 33.33 & 7.03 \\
$20-50$ & 256 & 4.45 & 18 & 3.95 & 13.51 \\
$>50$ & 111 & 1.93 & 15 & 3.29 & \\
\hline
\end{tabular}

Notes: (1) $1 \mathrm{li}=500 \mathrm{~m}$; (2) Proportion of the total entrepreneurship sample $(\%)=$ the number of entrepreneurship samples in the stage/the number of entrepreneurship samples in the entire sample; (3) Entrepreneurship rate of this stage $(\%)=$ the number of entrepreneurship samples in the stage/the number of total samples in the stage.

\subsection{Comparison of Urban and Rural Differences}

In order to further examine the various role of the community environment in individual entrepreneurship, the authors make a comparison between urban and rural communities. Given the characteristics of urban economies and the lack of some indicators compared with rural samples, the indicators representing the urban-rural distance in the location (C_trans_town, C_trans_city), population economic activity (C_mobility), and economic resource (C_resource) are eliminated. The same treatment mentioned above is conducted on the urban entrepreneurship samples. The regression results are shown in Table 4.

Among the indicators of the social, institutional, and economic dimensions of the community environment in Model III (Urban), C_entre_p, C_mental, and C_eco pass the significance test under the level of 0.05 . C_entre_p and C_mental are negatively correlated with entrepreneurship, while C_eco is positively correlated with entrepreneurship, and has the highest OR (1.236). The other variables of the community environment are not significant. The result shows that entrepreneurship in urban areas is positively stimulated by the economic level of the community, while it has no significant relation to the social dimensions of the community. Compared with rural samples, there is no significant relationship between C_entre_atmos and entrepreneurship in urban communities, and the role of communities is mainly reflected in the positive influence of economic level. These evidences are quite different from those in rural communities, which highlight the importance of three dimensions of the community environment, especially informal institutions in rural entrepreneurship, as analyzed above.

\section{Conclusions and Discussion}

This paper extends the concept of mixed embeddedness originating in immigrant entrepreneurship research to discuss the impact of the rural community environment on the entrepreneurial activities of farmers in China. The findings show that farmer entrepreneurship is embedded into the social, economic, and institutional context at the community scale. This result gives a response to the contextualization issue that the entrepreneurship research in developing countries, including China, has overlooked, and also is in line with Pike's proposal [3], namely necessarily interpreting the question of "who is embedded in what?" when utilizing the embeddedness concept, which is one major contribution of the paper. Moreover, rural communities, as self-governing organizations in rural areas of China, bring about the agglomeration effect on entrepreneurial activities, and such effect is more prominent in comparison with urban communities. This result shows to a certain extent the attachments between farmer entrepreneurship and their rural communities, and further proves that rural entrepreneurship is indeed different from urban entrepreneurship [6], and rural communities in China deserve academic attention. This is another contribution of this article. 
This paper gets the main conclusions as follows. First, compared with kinships or blood-based relationships, neighborhood relationships and the weak ties based on population mobility in rural communities are more important for entrepreneurial activities. It shows that the social context of rural communities of China has been changing, although Chinese rural society is basically constructed within the traditional framework of the diversity-orderly pattern. The more harmonious the neighborhood relationships, the higher the community's entrepreneurship level will be. It also implies that the strategy of harmonious society construction that the Chinese central government has implemented for a long time [78] is of importance in the rural vitalization through encouraging farmer entrepreneurship. In combination with 'work experience', which is a control variable playing a strong role in promoting rural entrepreneurship, it is elicited that the social relationships embedded in entrepreneurial activities to an extent are resource-orientated.

Second, the impact of informal institutional embeddedness on rural entrepreneurial activities is more important than that of social embeddedness. The informal institutions, including the entrepreneurial culture created by self-established enterprises in the community, promote individual entrepreneurial activities, and have greater effects on rural entrepreneurship than social and economic environments. It means rural communities where local residences have no strong entrepreneurial spirits or traditions also have the possibility of cultivating entrepreneurial climate by setting up community-based enterprises. Compared with informal institutions, formal institutions have a less prominent impact on rural entrepreneurial activities. It implies that only a handful of farmers benefit from the governmental policies concerning building up industrial parks, and local government should pay more attention to the demands and accessibility of physical and mental supports for farmer entrepreneurship in rural areas.

Third, rural entrepreneurial activities are related to the economic level and infrastructure level of the rural communities, as well as their economic location. Rural communities are local production places and consumption markets; the geographical proximity to central cities or towns brings about market opportunities, which in turn affect rural entrepreneurship. It implies that strengthening the infrastructure construction, increasing the investment and financing vitality, and improving the connections to the central towns are beneficial to rural entrepreneurship and revitalization.

This paper also has several defects. First of all, the dependent variable, rural entrepreneurship, which was measured by the indicator "whether to engage in individual and private business", probably makes the results a little bit biased, as a small number of innovation-based entrepreneurial activities in rural areas has been excluded. Secondly, the relationship between the community and the external regions (rather than the neighboring central cities or towns) has not been examined in this research. In particular, the issue of how rural entrepreneurial activities are embedded within the global context has not been explored. Thirdly, due to the limitation of the CFPS data, different stages of farmer entrepreneurship were not taken into consideration. Furthermore, due to the lack of detailed information from data such as in-depth interviews and the geographical information and environmental characteristics of the community samples, little has been dealt with regarding the spatial analysis of entrepreneurial activities, which needs further improvement.

Author Contributions: H.Z. contributed to the theoretical framework of the paper; Y.C. contributed to data analysis, and K.C. contributed to the data collection.

Funding: This research was funded by National Key R\&D Program of China (No. 2017YFA0603602) and National Natural Science Foundation of China (No. 41171098).

Acknowledgments: The authors would like to appreciate three anonymous referees for their constructive comments. They also would like to extend their thanks to the guest editor of the special issue and the assistant editors of Sustainability Editorial Office.

Conflicts of Interest: The authors declare no conflicts of interest. 


\section{Appendix A}

(a) "Wenzhou model" is based on family management as well as the individual and private economy; "Southern Jiangsu model" is promoted by local governments that mainly focus on developing townships collective enterprises; "Pearl River Delta region model" has an equal emphasis on township collective enterprises and the export-oriented economy; and "Jinjiang model" is mainly based on the market economy shared-cooperation system.

(b) Since the early 1990s, a large number China's rurally registered population have moved to urban areas for work, and these immigrants began to return in large numbers recently due to restrictions on urban household registration and social welfare. That is called as 'round trip migration'.

(c) Vacancy-chain openings refers to the stagnant or declining sunset sector, while post-industrial low-skill openings refers to the new sector that provides the service demands of an increasing occupational population with a high income and little time [57].

\section{References}

1. Harpa, E.; Moca, S.; Rus, D. A Comparative Study of Rural Entrepreneurship Romania-Greece. Procedia Technol. 2016, 22, 1100-1105. [CrossRef]

2. Friederike, W.; Ted, B.; Katharine, W. Three waves and counting: The rising tide of contextualization in entrepreneurship research. Small Bus. Econ. 2018. [CrossRef]

3. Baumol, W. Entrepreneurship: Productive, Unproductive, and Destructive. J. Political Econ. 1990, 98, 893-921. [CrossRef]

4. Andrea, G.; Christofer, L.; Christian, S.; Klas, E.; Rasmus, N. Digital entrepreneurship and field conditions for institutional change- investigating the enabling role of cities. Technol. Forecast. Soc. Chang. 2018. [CrossRef]

5. Stathopoulou, S.; Psaltopoulos, D.; Skuras, D. Rural entrepreneurship in Europe. Int. J. Entrep. Behav. Res. 2009, 10, 404-425. [CrossRef]

6. Greenberg, Z.; Farja, Y.; Gimmon, E. Embeddedness and growth of small businesses in rural regions. J. Rural Stud. 2018, 62, 174-182. [CrossRef]

7. Zhai, Q.; $\mathrm{Su}, \mathrm{J} . ; \mathrm{Ye}, \mathrm{M}$. Focus on China: The current status of entrepreneurship research in China. Scientometrics 2014, 98, 1985-2006. [CrossRef]

8. The CPC Central Committee and the State Council Issued the Strategic Plan for Rural Revitalization (2018-2022). Available online: http:// politics.people.com.cn/n1/2018/0926/c1001-30315263.html (accessed on 14 January 2019).

9. Belz, F.M.; Binder, J.K. Sustainable Entrepreneurship: A Convergent Process Model. Bus. Strategy Environ. 2017, 26, 1-17. [CrossRef]

10. Munoz, S.; Steiner, A.; Farmer, J. Processes of community-led social enterprise development: Learning from the rural context. Community Dev. J. 2015, 50, 478-493. [CrossRef]

11. Pike, A.; Lagendijk, A.; Vale, M. Critical reflections on 'embeddedness' in economic geography: Labour market governance in the North East region of England. In Restructuring Industry and Territory: The Experience of Europe's Regions; Giunta, A., Lagendijk, A., Pike, A., Eds.; TSO: London, UK, 2000; pp. 59-82.

12. Jack, S.L.; Anderson, A.R. The effects of embeddedness on the entrepreneurial process. J. Bus. Ventur. 2002, 17, 467-487. [CrossRef]

13. Kibler, E.; Fink, M.; Lang, R.; Muñoz, P. Place attachment and social legitimacy: Revisiting the sustainable entrepreneurship journey. J. Bus. Ventur. Insights 2015, 3, 24-29. [CrossRef]

14. Li, H.; Yang, Z.; Yao, X.; Zhang, H.; Zhang, J. Entrepreneurship, private economy and growth: Evidence from China. China Econ. Rev. 2012, 23, 948-961. [CrossRef]

15. Iskandarini. The impact of entrepreneurial barrier toward entrepreneurial intention for decreasing unemployment through community empowerment. Procedia Soc. Behav. Sci. 2014, 115, 166-174.

16. Peredo, A.; Chrisman, J. Toward a theory of community-based enterprise. Acad. Manag. Rev. 2006, 31, 309-328. [CrossRef]

17. Gurau, C.; Dana, L. Environmentally-driven community entrepreneurship: Mapping the link between natural environment, local community and entrepreneurship. Technol. Forecast. Soc. Chang. 2018, 129, 221-231. [CrossRef] 
18. Jennings, P.D.; Greenwood, R.; Lounsbury, M.D.; Suddaby, R. Institutions, entrepreneurs, and communities: A special issue on entrepreneurship. J. Bus. Ventur. 2013, 28, 1-9. [CrossRef]

19. Marti, I.; Courpasson, D.; Barbosa, S.D. "Living in the fishbowl”. Generating an entrepreneurial culture in a local community in Argentina. J. Bus. Ventur. 2013, 28, 10-29. [CrossRef]

20. Marquis, C.; Lounsbury, M. Vive la resistance: Competing logics and the consolidation of US community banking. Acad. Manag. J. 2007, 50, 799-820. [CrossRef]

21. Richard, L.; Matthias, F. Rural social entrepreneurship: The role of social capital within and across institutional levels. J. Rural Stud. 2018. [CrossRef]

22. Opinions of the CPC Central Committee and The State Council on Strengthening and Improving Urban and Rural Community Governance. Available online: http:/ /www.gov.cn/xinwen/2017-06/12/content_ 5201910.htm (accessed on 14 January 2019).

23. The General Office of the CPC Central Committee and the General Office of the State Council Have Issued the Guidance on Deepening the Pilot Work of Rural Community Construction. Available online: http:/ / www.gov.cn/xinwen/2015-05/31/content_2871051.htm (accessed on 14 January 2019).

24. Jin, H.; Qian, Y. Public versus private ownership of firms: Evidence from rural China. Q. J. Econ. 1998, 113, 773-808. [CrossRef]

25. Beck, T.; Lu, L.; Yang, R. Finance and growth for microenterprises: Evidence from rural China. Soc. Sci. Electron. Publ. 2015, 67, 38-56. [CrossRef]

26. Polanyi, K. The Great Transformation: The Political and Economic Origins of Our Time; Beacon Press: Boston, MA, USA, 1944; pp. 1-364.

27. Granovetter, M. Economic action and social structure: The problem of embeddedness. Am. J. Sociol. 1985, 91, 481-510. [CrossRef]

28. Zukin, S.; DiMaggio, P. Structures of Capital. The Social Organization of the Economy; Cambridge University Press: Cambridge, UK, 1990; pp. 1-461.

29. Kloosterman, R.; Van Der Leun, J.; Rath, J. Mixed embeddedness: (in) formal economic activities and immigrant businesses in the Netherlands. Int. J. Urban Reg. Res. 1999, 23, 252-266. [CrossRef]

30. Bouk, F.E.; Vedder, P.; Poel, Y.T. The networking behavior of Moroccan and Turkish immigrant entrepreneurs in two Dutch neighborhoods: The role of ethnic density. Ethnicities 2013, 13, 771-794. [CrossRef]

31. Amine, L.; Staub, K. Women entrepreneurs in sub-Saharan Africa: An institutional theory analysis from a social marketing point of view. Entrep. Reg. Dev. 2009, 21, 183-211. [CrossRef]

32. Langevang, T.; Gough, K.; Yankson, P.; Owusu, G.; Osei, R. Bounded entrepreneurial vitality: The mixed embeddedness of female entrepreneurship. Econ. Geogr. 2015, 91, 449-473. [CrossRef]

33. Zhu, H.S.; Liu, X. Isolated from the City? Urban-Rural Immigrants' Entrepreneurship in the Urban Fringe Area of Suzhou, China. Econ. Geogr. 2013, 33, 135-153. (In Chinese)

34. Démurger, S.; Xu, H. Return migrants: The rise of new entrepreneurs in rural china. World Dev. 2011, 39, 1847-1861. [CrossRef]

35. Kalantaridis, C. In-Migration, Entrepreneurship and Rural-Urban Interdependencies: The Case of East Cleveland, North East England. J. Rural Stud. 2010, 26, 418-427. [CrossRef]

36. Jones, T.; Ram, M.; Edwards, P.; Kiselinchev, A.; Muchenje, L. Mixed embeddedness and new migrant enterprise in the UK. Entrep. Reg. Dev. 2014, 26, 500-520. [CrossRef]

37. Vial, V. Micro-entrepreneurship in a hostile environment: Evidence from Indonesia. Bull. Indones. Econ. Stud. 2011, 47, 233-262. [CrossRef]

38. Ndofor, H.A.; Priem, R.L. Immigrant entrepreneurs, the ethnic enclave strategy, and venture performance. J. Manag. 2011, 37, 790-818.

39. Morrison, C.; Ramsey, E. Power to the people: Developing networks through rural community energy schemes. J. Rural Stud. 2018. [CrossRef]

40. Fei, X.T. Earthbound China, 1st ed.; People's Publishing House: Beijing, China, 2015; pp. 25-35, ISBN 978-7-01-014714-7. (In Chinese)

41. Greve, A.; Salaff, J. Social Networks and Entrepreneurship. Entrep. Theory Pract. 2003, 28, 1-22. [CrossRef]

42. Schutjens, V.; Völker, B. Space and Social Capital: The Degree of Locality in Entrepreneurs' Contacts and its Consequences for Firm Success. Eur. Plan. Stud. 2010, 18, 941-963. [CrossRef]

43. Liang, Z.; Zhao, Z. What drives spatial clusters of entrepreneurship in China? Evidence from economic census data. China Econ. Rev. 2017, 46, 229-248. 
44. Granovetter, M.S. The strength of weak ties. Am. J. Sociol. 1973, 78, 1360-1380. [CrossRef]

45. Welter, F.; Smallbone, D. Institutional perspectives on entrepreneurial behavior in challenging environments. J. Small Bus. Manag. 2011, 49, 107-125. [CrossRef]

46. Scott, W.R. Institutions and Organizations: Ideas, Interests and Identities, 4th ed.; SAGE Publications: Thousand Oaks, CA, USA, 2014; pp. 47-70.

47. Aliaga-Isla, R.; Rialp, A. Systematic review of immigrant entrepreneurship literature: Previous findings and ways forward. Entrep. Reg. Dev. 2013, 25, 819-844. [CrossRef]

48. Zhu, H.; Hitt, M.A.; Tihanyi, L. The internationalization of SMEs in emerging economies: Institutional embeddedness and absorptive capacities. J. Small Bus. Strategy 2006, 17, 1.

49. Yang, K. Institutional holes and entrepreneurship in China. Sociol. Rev. 2004, 52, 371-389. [CrossRef]

50. Wu, J.; Zhuo, S.; Wu, Z. National innovation system, social entrepreneurship, and rural economic growth in China. Technol. Forecast. Soc. Chang. 2016. [CrossRef]

51. GEM 2017/2018 Global Report. Available online: https://www.gemconsortium.org/report/50012 (accessed on 6 April 2018).

52. Circular of the Ministry of Agriculture on Publishing the Catalogue of National Rural Entrepreneurship and Innovation Parks (Bases). Available online: http:/ / www.moa.gov.cn/nybgb/2017/dqq/201712/t20171230_ 6133922.htm (accessed on 17 February 2019).

53. Puffer, S.M.; Mccarthy, D.J.; Boisot, M. Entrepreneurship in Russia and China: The impact of formal institutional voids. Entrep. Theory Pract. 2010, 34, 441-467. [CrossRef]

54. Beugelsdijk, S. Entrepreneurial culture, regional innovativeness and economic growth. In Entrepreneurship and Culture; Freytag, A., Thurik, R., Eds.; Springer Berlin Heidelberg: Berlin/Heidelberg, Germany, 2010; pp. 129-154, ISBN 9783540879091.

55. Lyon, M.H.; West, B.J.M. London Patels: Caste and commerce. J. Ethn. Migr. Stud. 1995, 21, $399-419$. [CrossRef]

56. Pierre, A.; Friedrichs, Y.V.; Wincent, J.; Friedrichs, Y. Entrepreneurship in society: A review and definition of community-based entrepreneurship research. In Social Entrepreneurship: Leveraging Economic, Political, and Cultural Dimensions; Lundström, A., Zhou, C., von Friedrichs, Y., Sundin, E., Eds.; Springer: Cham, Switzerland, 2014; Volume 29, pp. 239-257, ISBN 978-3-319-01396-1.

57. Sassen, S. Losing Control: Sovereignty in an Age of Globalization, 1st ed.; Columbia University Press: New York, NY, USA, 1996; pp. 1-128, ISBN 0231106084.

58. Samli, A.C. Entrepreneurship economic development and quality of life in third-world countries. Appl. Res. Qual. Life 2008, 3, 203-213. [CrossRef]

59. Bosworth, G.; Glasgow, N. Entrepreneurial behaviour among rural in-migrants. In Rural Transformations and Rural Policies in the US and UK (Routledge Studies in Development and Society), 1st ed.; Shucksmith, M., Brown, D.L., Shortall, S., Vergunst, J., Warner, M.E., Eds.; Routledge: New York, NY, USA, 2012; pp. 138-155, ISBN 978-0-415-89010-6.

60. Murdoch, J. Networks-A new paradigm of rural development? J. Rural Stud. 2000, 16, 407-419. [CrossRef]

61. Mair, J.; Martí, I.; Ventresca, M.J. Building inclusive markets in rural Bangladesh: How intermediaries work institutional voids. Acad. Manag. J. 2012, 55, 819-850. [CrossRef]

62. Krugman, P. Increasing returns and economic geography. J. Polit. Econ. 1991, 99, 483-499. [CrossRef]

63. De Janvry, A.; Sadoulet, E.; Zhu, N. The role of non-farm incomes in reducing rural poverty and inequality in China. Cudare Work. Pap. 2005, 1-29.

64. Winters, P.; Davis, B.; Carletto, G.; Covarrubias, K.; Quiñones, E.J.; Zezza, A. Assets, activities and rural income generation: Evidence from a multicountry analysis. World Dev. 2009, 37, 1435-1452. [CrossRef]

65. Winters, P.; Davis, B.; Corral, L. Assets, activities and income generation in rural Mexico: Factoring in social and public capital. Agric. Econ. 2002, 27, 139-156. [CrossRef]

66. Institute of Social Science Survey PU (2019) China Family Panel Studies (CFPS). Peking University Open Research Data Platform. Available online: http://dx.doi.org/10.18170/DVN/45LCSO (accessed on 14 January 2019).

67. Faggio, G.; Silva, O. Self-employment and entrepreneurship in urban and rural labour markets. J. Urban Econ. 2014, 84, 67-85. [CrossRef]

68. Schnell, I.; Greenberg, Z.; Arnon, S.; Shamai, S. Entrepreneurship in the periphery and local growth: The case of northern Israel. GeoJournal 2017, 82, 217-229. [CrossRef] 
69. Autio, E.; Acs, Z.J. Intellectual property protection and the formation of entrepreneurial growth aspirations. Strateg. Entrep. J. 2010, 4, 234-251. [CrossRef]

70. Yueh, L. China's Entrepreneurs. World Dev. 2009, 37, 778-786. [CrossRef]

71. Kim, P.H.; Aldrich, H.E.; Keister, L.A. Access (not) denied: The impact of financial, human, and cultural capital on entrepreneurial entry in the United States. Small Bus. Econ. 2006, 27, 5-22. [CrossRef]

72. Cai, L.; Hughes, M.; Yin, M.M. The Relationship between Resource Acquisition Methods and Firm Performance in Chinese New Ventures: The Intermediate Effect of Learning Capability. J. Small Bus. Manag. 2014, 52, 365-389. [CrossRef]

73. Davidsson, P.; Wiklund, J. Levels of analysis in entrepreneurship research: Current research practice and suggestions for the future. Entrep. Theory Pract. 2001, 25, 81-100. [CrossRef]

74. Bygrave, W.; Hay, M.; Ng, E.; Reynolds, P.; Mason, C.; Harrison, R.T. Executive forum: A study of informal investing in 29 nations composing the global entrepreneurship monitor. Ventur. Cap. 2003, 5, 101-116. [CrossRef]

75. Siddiqui, A.; Siddiqui, A.; Maithani, S.; Jha, A.K.; Kumar, P.; Srivastav, S.K. Urban growth dynamics of an Indian metropolitan using ca markov and logistic regression. Egypt. J. Remote Sens. Space Sci. 2017. [CrossRef]

76. Rui, X.; Yue, L.; Xin, H.; Ruixing, S.; Weixuan, Y.; Tao, Z. Exploring the driving forces of farmland loss under rapid urbanization using binary logistic regression and spatial regression: A case study of shanghai and hangzhou bay. Ecol. Indic. 2018, 95, 455-467.

77. Héctor, M.R.; Ollero, J.; Alfonso, S. A new explanatory index for evaluating the binary logistic regression based on the sensitivity of the estimated model. Stat. Probab. Lett. 2017, 120, 135-140.

78. Building Harmonious Communities and Promoting Neighborhood Harmony. Available online: http:/ / www. china.com.cn/policy/zhuanti/hxsh/txt/2007-02/05/content_7762133.htm (accessed on 17 February 2019).

(C) 2019 by the authors. Licensee MDPI, Basel, Switzerland. This article is an open access article distributed under the terms and conditions of the Creative Commons Attribution (CC BY) license (http://creativecommons.org/licenses/by/4.0/). 